\title{
Review of Latex Allergy
}

\author{
Lester Cheng, $M D$, and Daniel Lee, $M D$
}

Background: Allergy to latex has become an increasing concern to many patients and health care providers. Health care providers should become aware of this problem and develop strategies for treatment and prevention.

Methods: We searched MEDLINE from 1990 to 1998 for the topics of latex allergy using the key words "latex" and "allergy." Other sources were found from back-referencing these references and from the Internet.

Results: Latex allergy is emerging as a clinical and occupational health problem. Understanding the clinical and immunologic features, which range from dermatitis to anaphylaxis, can provide the basis of preventive and therapeutic strategies.

Conclusion: The clinician should be able to recognize latex allergy and educate patients about the potential hazards of latex-containing products. Providers can develop a plan for protecting patients and health care staff from latex exposure as well as treating allergic reactions when they occur. (J Am Board Fam Pract 1999;12:285-92.)

In recent years patients and health care workers have experienced a marked increase in serious allergic reactions to latex ${ }^{1}$ as a result of the increased exposure and sensitization to latex products in the health care industry, particularly latex gloves. Universal precautions were implemented as a health care policy in 1987 as a result of the human immunodeficiency virus (HIV) epidemic and spread of hepatitis. At that time 1 billion gloves were imported into the United States annually. The following year more than 8 billion gloves were imported. ${ }^{2}$ This dramatic increase in the use of latex gloves has greatly contributed to the higher incidence of latex allergic reactions. Moreover, patients and health care workers are not the only ones at risk for latex exposure. With more than 40,000 commercial products in the marketplace that contain latex, persons in other occupations and a considerable portion of the general population are at risk for latex exposure and sensitization.

\section{Methods}

More than 500 titles were found during a search of the medical literature from 1990 to 1998 in

Submitted, revised, 19 February 1999.

From the Santa Monica-UCLA Family Practice Residency Program (LC, DL), and the Department of Family Medicine, UCLA School of Medicine (DL), Santa Monica, Calif. Address reprint requests to Daniel Lee, MD, 125515 th St, Santa Monica, CA 90404.
MEDLINE using the key words "latex" and "allergy." These articles were reviewed based on their relevance to this review. Additional articles dating before 1990 were accessed by cross-referencing the more recent articles.

\section{Epidemiology \\ General Population}

The overall incidence of latex allergy is unknown, but the prevalence in the general nonatopic population is estimated to be less than 1 percent. ${ }^{3}$ In a recent study in Detroit, however, 1000 blood donors were tested for immunoglobulin $\mathrm{E}$ (IgE) specificity for latex. Results showed a 6.4 percent positive response, which suggests a much higher prevalence in the general population than first presumed. ${ }^{4}$ These results were basically replicated in another study, where the prevalence of latex sensitization in persons attending health screening was 6.6 percent. ${ }^{5}$

\section{Patient Population}

In the fall of 1989, the Food and Drug Administration (FDA) began receiving reports of patients going into anaphylactic shock while receiving barium enemas. Barium was originally suspected as the sole culprit, but it was soon discovered that the latex-cuffed enema tip was the cause of 16 deaths overall. ${ }^{6}$ This finding led to an increased awareness of the risk of type 1 allergy associated with la- 
tex products. Patients with spina bifida are at increased risk for latex sensitization because they are frequently exposed to latex from urethral catheterizations, multiple surgeries, and ventriculoperitoneal shunt placement early in life. The prevalence of allergy in these patients ranges from 28 to 67 percent. ${ }^{7}$ Pediatric patients with spina bifida have a risk of latex-related anaphylaxis during surgery that is 500 times greater than that of the general population. The marked increase in latex allergy in these spina bifida patients more likely results from extensive latex exposure early in life rather than a genetic predisposition.

Pregnant woman have also been found to be at risk for sensitization to latex. Four women developed systemic allergic reactions during delivery as a result of exposure to surgical latex gloves worn by the obstetrician. ${ }^{8}$ In another study the incidence of latex sensitivity in an ambulatory surgical population was also found to be 6.7 percent $(n-996) .{ }^{9}$

\section{Health Care Workers}

The prevalence of latex allergy among health care workers is estimated between 5 to 10 percent. ${ }^{3,10,11}$ In a study of registered nurses the prevalence of latex sensitization was 8.9 percent $(n-741) .{ }^{12}$ In another study the prevalence of latex sensitization in a hospital employee population was approximately 8 percent ( $n-135),{ }^{13}$ and in another hospital setting, the prevalence of latex sensitization was 12.1 percent among workers $(\mathrm{n}-1351) .^{14}$

\section{Other At-Risk Populations}

Workers in the latex-manufacturing industry are also at risk, with one glove-manufacturing plant reporting a 3.7 percent prevalence of occupational asthma based on positive skin-prick testing and spirometric data. ${ }^{15}$ Workers at a latex doll-manufacturing plant were also found to be sensitized to latex sensitization. ${ }^{16}$ Many other persons are at risk, especially the police and emergency medical personnel, food handlers who work in cafeterias and fast-food restaurants, and sanitation engineers in various fields, all of whom can wear latex gloves for prolonged periods.

\section{Atopic Patients}

Persons with atopy have higher risk for latex allergy. Two studies found that 54 and 57 percent of persons with latex allergy had a history of atopy (asthma, rhinitis, or food allergy). ${ }^{17,18}$ In the same study it was estimated that 2.5 percent of hospital employees had occupational asthma secondary to latex hypersensitivity. ${ }^{18}$ The prevalence of latexspecific IgE antibodies in atopic and nonatopic children with type 1 diabetes was 6 percent compared with 0.37 percent in the general population. The high rate of sensitization to latex in children with diabetes is secondary to the high rate of atopy in the study population. Atopic patients with diabetes, however, might be at risk for reactions secondary to latex from insulin vials and syringes. ${ }^{19}$ Finally, in patients being evaluated for allergy, the prevalence of latex-specific $\operatorname{IgE}$ antibodies was 12 percent. ${ }^{20}$

\section{Pathophysiology}

Latex is the milky sap obtained by tapping the rubber tree, Hevea brasiliensis. It is derived from cells of the lactiferous system and is easily harvested. ${ }^{21}$ The raw product is mixed with a preservative, such as ammonia; it is then concentrated and shipped as a latex concentrate. ${ }^{22}$ Commercial use began with the discovery of vulcanization in 1839 by Charles Goodyear. Vulcanization (heating in the presence of sulfur) greatly enhances the elasticity, strength, and stability of latex. Numerous chemical accelerators reduce the temperature and time required. ${ }^{23}$ These accelerators can cause allergic reactions and are responsible for many cases of contact dermatitis. ${ }^{10}$ Chemically, latex contains proteins, cis-polyisoprene, water, and lipids. The proteins cause the severe immediate hypersensitivity reactions. ${ }^{1,24}$

More than 50 different proteins have been implicated in the allergic response, with up to a total of 240 different proteins found in latex. ${ }^{25}$ Latex products are made either by pouring the rubber into molds or by forming a coating in a dipped process, as is done with gloves, balloons, and condoms. Dipped or very soft rubber products appear to have the highest content of latex proteins and, therefore, have the greatest allergenic potential.

Systemic reactions to latex can result from exposure to latex protein by various routes, including the skin, mucous membranes, inhalation, and intravascular or internal tissue. Medical devices that have been reported to trigger serious systemic reactions by cutaneous exposure include anesthetic masks, tourniquets, electrocardiogram electrodes, adhesive tapes, condom catheters, and ileostomy bags. Most severe reactions to latex have resulted 
Medical Products

Adhesive tape

Ambu bags

Blood pressure cuffs

Bulb syringes

Crutches

(arm and hand pads)

Electrocardiogram

electrode pads

Elastic bandages

Electrode pads

Endotracheal tube

Face masks, straps

Gloves

Mattresses on

stretchers
Nasopharyngeal and oropharyngeal airway tubes

Reservoir breathing

bags

Rubber syringe stoppers

Stethoscope tubing

Teeth protectors

Tourniquets

Tympanometers

Urinary catheters

Ventilator bellows and

hoses

Wheelchair tires,

cushions

Wound drains
Housebold and Personal Items

Automobile tires

Bath mats

Buttons on electronic

equipment

Carpet backing and pads

Computer mouse pads

Condoms

Contraceptive sponges

Diaphragms

Dishwashing gloves

Foam rubber

Hot water bottles

Pencil erasers

Rubber bands

Rubber cements
Infant and Cbild Items

Balloons

Bottle nipples

Elastic in clothing and dis-

posable diapers

Halloween masks

Infant pacifiers

Rubber balls

Rubber toys

Sports Items

Athletic shoe soles

Rubber boats

Scuba face masks

Sports racquet handles

Swimming caps and goggles from latex proteins contacting mucous membranes of the mouth, vagina, urethra, or rectum. Materials used in dentistry, including gloves, mouth bite plates, and orthodontic elastics, are potential allergic sources. For infants pacifiers might be a possible source of exposure to latex allergens early in life. ${ }^{26}$ Some of the most severe reactions to latex have resulted from contact between the rectal mucosa and balloon catheters used for barium enemas; these reactions are thought to be due to the high absorption rate of the rectum. ${ }^{6}$

Cornstarch powder is applied to latex gloves during the manufacturing process to prevent stickiness and to give the gloves a smooth feel. Latex protein particles have been shown to adhere to the surface of these cornstarch particles, which then become aerosolized on removal of the gloves. ${ }^{25,27}$ Airborne latex protein absorbed by the cornstarch glove powder has been found to be related to asthmatic reactions. Health care workers who use gloves or work in a latex-laden environment are thus susceptible to occupational bronchial asthma. ${ }^{28-30}$

Many case reports describe severe intraoperative anaphylaxis associated with surgical gloves coming into contact with the peritoneum and viscera; these tissues readily absorb the water-soluble latex proteins. ${ }^{30}$ Intravascular administration of latex proteins can result from disposable syringe plungers, medications stored in vials with rubber stoppers, and intravenous tubing with latex injection ports (Table 1). ${ }^{28,31}$

Because latex is a natural product of the rubber tree, many other fruits in this family of plants will have similar proteins. These proteins are so simi- lar that the immune system recognizes these as latex proteins and then responds to it. The most common cross-reactivity has been found between latex and such foods as banana, avocado, chestnut, passion fruit, kiwi fruit, potatoes, and tomatoes, all of which have been found to be antigenically similar to latex (Table 2)..$^{32}$ Other foods, including figs, apples, celery, melons, pineapples, milk, papayas, and grapes, and pitted fruits, such as cherries, peaches, and apricots, can also cross-react and cause symptoms. In one study, 42.6 percent of patients known to be allergic to latex reported allergic symptoms after ingestion of cross-reactive fruits, including kiwi, banana, pineapple, passion fruit, and mango. ${ }^{32}$

\section{Clinical Manifestations}

There are three main types of latex sensitivity reactions. Irritant contact dermatitis (nonimmune) has a gradual onset, taking days, and is caused by accelerators and chemicals used in the latex glove

Table 2. Foods That Cross-React With Latex.

\begin{tabular}{cl}
\hline $\begin{array}{c}\text { Common } \\
\text { Cross-Reactivity }\end{array}$ & $\begin{array}{c}\text { Other Foods } \\
\text { That Can Cross-React }\end{array}$ \\
\hline Avocado & Apples \\
Banana & Apricots \\
Chestnut & Celery \\
Kiwi fruit & Cherries \\
Passion fruit & Figs \\
Potato & Grapes \\
Tomato & Melons \\
& Milk \\
& Papayas \\
& Peaches \\
& Pineapples \\
\hline
\end{tabular}


Table 3. Questionnaire to Determine Latex Sensitivity.

\begin{tabular}{|c|c|}
\hline \multirow[t]{2}{*}{ Allergies } & $\begin{array}{l}\text { 1. Do you have a history of hay fever, eczema, asthma, hives, rashes, or allergic reactions } \\
\text { to certain drugs? }\end{array}$ \\
\hline & $\begin{array}{l}\text { 2. Do you have a history of allergic reactions (rash, swelling, oral itching, or wheezing) } \\
\text { after eating certain foods such as bananas, avocados, kiwi, chestnuts? }\end{array}$ \\
\hline \multirow[t]{3}{*}{ Occupationally related symptoms } & 3. Have you ever had an allergic response to something in your work environment? \\
\hline & 4. Are you exposed to any latex-containing products at work? \\
\hline & $\begin{array}{l}\text { 5. Have you ever developed a rash on your hands after wearing latex gloves? If so, how } \\
\text { long after wearing the gloves did the rash develop, and what did the rash look like? }\end{array}$ \\
\hline \multirow[t]{3}{*}{ Risk factors for latex allergy } & 6. Do you have spina bifida or urinary tract problems requiring frequent catheterizations? \\
\hline & 7. Have you ever had an operation? If so, how many? \\
\hline & 8. Have you ever worked in an environment with latex products? \\
\hline \multirow[t]{2}{*}{ Hidden reactions to latex } & $\begin{array}{l}\text { 9. Have you ever had a rash, swelling, shortness of breath, itching, cough, wheezing, or } \\
\text { itchy eyes while wearing household gloves, blowing up a balloon, using a condom or } \\
\text { diaphragms, or after a rectal or vaginal examination? }\end{array}$ \\
\hline & $\begin{array}{l}\text { 10. Have you ever had an allergic reaction without a known cause, especially during } \\
\text { surgery, hospitalization, or dental procedure? }\end{array}$ \\
\hline
\end{tabular}

manufacturing. Symptoms can include redness, cracks, fissures, and scaling. Allergic contact dermatitis, or type 4 (delayed hypersensitivity), has an onset 6 to 48 hours after contact. Symptoms, which are also caused by the accelerators and chemicals, include erythema, vesicles, papules, pruritus, blisters, and crusting. These lesions can resemble those caused by poison ivy or poison oak. Approximately 80 percent of the immunologic reactions are type 4 .

The third type of reaction is immediate hypersensitivity, or type $1-\operatorname{IgE}$ mediated reaction, which is caused by the latex proteins. Its onset occurs within minutes and rarely lasts longer than 2 hours. These symptoms include local and generalized urticaria, lightheadedness, angioedema, nausea, vomiting, abdominal cramps, rhinoconjunctivitis, bronchospasm, and anaphylactic shock. It is possible to have used latex for years without problems and suddenly progress to systemic symptoms. Anaphylactic reactions to latex have been reported in persons who had previously experienced only irritant or allergic contact dermatitis. ${ }^{25}$

\section{Diagnosis}

Because any product containing latex can trigger a reaction, cautious investigation of products at home, in the workplace, and at sites of medical and dental care should occur. A thorough medical history is the cornerstone of the diagnosis of latex allergy. The patient should be asked about occupational and other risk factors. Furthermore, the history should determine whether previous reac- tions have occurred and, if so, what type of reactions. A history of reactivity to foods, symptoms following use of a rubber condom or diaphragm, or symptoms associated with pelvic examination should raise the suspicion of latex sensitivity (Table 3).

Because of the lack of awareness of latex allergy or a concomitant history of atopic illness or both, sensitized persons typically do not attribute their respiratory symptoms of rhinoconjunctivitis or bronchospasm to latex exposure. For this reason, eliciting a history suggestive of latex allergy is vitally important before undertaking any elective procedure during which latex exposure will occur. In one study, however, none of the patients whose deaths were attributed to anaphylaxis caused by latex exposure had any known risk factors other than atopic illness, illustrating that even taking the above precautions can be insufficient. ${ }^{33}$

Standardized extracts for skin-prick testing are not readily available in the United States. Because such testing can cause an anaphylactic response, these tests should be conducted only at centers that have staff experienced in preparing extracts. FDA-approved in-vitro tests to measure latexspecific IgE are available (Pharmacia CAP, Pharmacia-Upjohn Diagnostics, Kalamazoo, Mich; AlaSTAT, Diagnostic Products Corps, Los Angeles, Calif) ${ }^{34}$ The low specificity of these tests limits their clinical usefulness. A negative serologic test despite a strong positive history of sensitivity would suggest the value of skin-prick testing to confirm the diagnosis. ${ }^{25}$ 
Table 4. Nonlatex Gloves and Product Source.

\begin{tabular}{ll}
\hline Material & Product (Manufacturer) \\
\hline Vinyl & $\begin{array}{l}\text { TruTouch (Becton Dickinson) } \\
\text { Vinylite (SmartPractice) } \\
\text { Allerderm vinyl (Allerderm Labs) } \\
\text { Royal Shield (SmartCare) }\end{array}$ \\
& SensiCare (Becton Dickinson) \\
& Triflex vinyl (Baxter Pharmaseal) \\
& N-dex (Best Company) \\
Nitrile & Nitrile (Pure Advantage) \\
& Allerderm Nitrile (Allerderm Labs) \\
& Dermaprene (Ansell) \\
Neoprene & Neolon (Becton Dickinson) \\
Thermoplastic & TactyLite (SmartCare) \\
elastomer & Allergard (Johnson \& Johnson) \\
& Tactyl 1 (Allerderm Labs) \\
Styrene-butadiene & Elastyren (Hermal) \\
block polymer & \\
\hline
\end{tabular}

Adapted from Kam et al. ${ }^{28}$

\section{Treatment of Reactions}

Acute systemic reactions to latex should be treated in the same manner as any anaphylactic reaction. The airway, breathing, and circulation are assessed, oxygen is provided, and epinephrine and steroids are administered. Diphenhydramine (Benadryl) can be used for urticarial reactions. In the course of resuscitation, all contact with latex products should be avoided. Fluids and nebulized medications for bronchospasm might be required. Treatment should be continued with monitoring until after symptoms resolve. It is ironic that for the exquisitely latex-sensitive person who develops a type 1 hypersensitivity reaction, the hospital and emergency department settings can be most fraught with danger because of the great amount of latex found in medical equipment. Growing awareness of the magnitude of health risk posed by latex allergy might improve this paradoxical situation. ${ }^{25}$

\section{Management Issues}

In 1991 the FDA recommended that all patients be questioned for potential latex allergy, particularly those with spina bifida or any patient scheduled for surgical or diagnostic procedures. All physicians are requested to report all episodes of anaphylaxis during procedures requiring general anesthesia through state health departments to the epidemiology branch of the hospital infections program at the National Center for Infectious

Table 5. Operating Room Guidelines for Patients With Latex Allergy.

\begin{tabular}{|c|c|}
\hline Latex Items & Nonlatex Alternatives \\
\hline \multicolumn{2}{|l|}{ Implements } \\
\hline Bulb syringes & Jackson Pratt Evacuator Bulb (Davol relia Vac \#100) \\
\hline Blanket warning mattress & Completely cover with linen \\
\hline Blood pressure cuff and tubing & Wrap with gauze or latex-free tape \\
\hline Catheters (Foley, caude, Malecot, red rubber) & Silicon (Silastic) Foley catheter, feeding tubes, nasogastric tubes \\
\hline Chest tube drainage system tubing & Wrap with gauze or latex-free tape \\
\hline Electrocardiogram lead cords & Wrap with gauze or latex-free tape \\
\hline Fenestrated sheets & Large sheets cut into shape for opening \\
\hline \multirow[t]{2}{*}{ Gloves } & TactyLite gloves, sterile $6 \frac{1}{2}$ to $81 / 2$ \\
\hline & SensiCare nonlatex gloves 7 to $7 \mathrm{l} / 2,8$ to $81 / 2$ \\
\hline Neuro suction tubing & Neuro-Frazier Suction Connecting Tubing (Davol \# 3100) \\
\hline \multicolumn{2}{|l|}{ Medications } \\
\hline Intravenous irrigation solutions & Do not puncture rubber ports, use stopcocks \\
\hline Multiple medicine vials & Remove the rubber stoppers \\
\hline Penrose drains & Jackson Pratt (Davol) drains, Hemovacs \\
\hline Power cords & Drape with Cireon Camerce cover \\
\hline Rubber bands & Steri Strips \\
\hline Syringes with black latex stopper & Glass syringes \\
\hline $\begin{array}{l}\text { Tapes, elastic bandages (Elastoplast, Ace), } \\
\text { adhesive bandages (Band-Aids), }\end{array}$ & Paper or sirk tapes only \\
\hline Tourniquets & Nonlatex glove \\
\hline Urometer & Remove rubber tip, use straight connector \\
\hline Utility drapes (stickers) & Linen towels \\
\hline
\end{tabular}




\section{Disease, Centers for Disease Control. ${ }^{35,36}$}

In the health care setting, the two major strategies for management are (1) prevention and treatment of occupational latex allergy in employees, and (2) the safe care of the latex-allergic patient. The cornerstone of latex allergy treatment is avoidance. Many persons who are constantly exposed to the powdered latex glove are likely to become sensitized. Workplace decisions should be made to reduce cumulative exposure to latex, including the widespread purchase of nonlatex gloves or nonpowdered, low-protein latex gloves.

Covering skin cuts on hands with adhesive bandages before donning latex gloves might help prevent increased $\mathrm{IgE}$ production. In addition, putting on powdered gloves cautiously will help prevent inhalation of the aerosolized latex proteins. Some newer glove products have very low soluble and aerosol titers of proteins, but wide variation remains between brands. For health care workers and patients who are allergic to latex, nonlatex gloves should be used (Table 4). The $\mathrm{Na}$ tional Institute of Occupational Safety and Health (NIOSH) recently published an advisory document on natural latex rubber in the workplace. It recommends that nonlatex gloves be used for all activities that are not likely to involve contact with infectious materials (eg, food preparation, routine housekeeping and maintenance). ${ }^{37}$

In caring for the patient with latex sensitivity, the distinctions between a true type 1 and irritant and allergic contact dermatitis reactions caused by other factors must be considered. Any evidence of a history of type 1 reactions necessitates a latexfree environment. In the hospital setting protocols for the emergency department, operating room, in-patient rooms, and other areas where patients might come into contact with latex should be established and should be available to all hospital staff, including housekeeping staff (Tables 5 and 6). At the time of admission, latex allergy status should be established by the history or screening questionnaire. Status should be documented and prominently displayed at the door, at the bedside, and on wristbands. Emergency department, operating department, and crash cart supplies should include nonlatex products. Note that so-called hypoallergenic latex gloves are not necessarily latexfree; they can contain considerable amounts of latex allergens and should not be worn in the vicinity of persons who are allergic to latex.
Table 6. Items Contained in Latex-Free Box.

\begin{tabular}{|c|c|}
\hline Item or Product Name & Manufacturer \\
\hline $\begin{array}{l}\text { Nonsterile examination gloves } \\
\text { (Nitrile Plus) }\end{array}$ & Biosafety Systems \\
\hline $\begin{array}{l}\text { Duraprene sterile synthetic surgeon's } \\
\text { gloves (size } 61 / 2 \text { to } 8 \text { ) }\end{array}$ & Baxter Healthcare \\
\hline AstroScope disposable stethoscope & Omron Healthcare \\
\hline $\begin{array}{l}\text { Large adult personal cuff } \\
\text { (blood pressure cuff) }\end{array}$ & Technol \\
\hline Adult personal cuff & Technol \\
\hline Small adult personal cuff & Technol \\
\hline Child cuff & Technol \\
\hline Child cuff (size 5) & Technol \\
\hline Pediatric cuff (size 4) & Technol \\
\hline Infant cuff (size 3) & Technol \\
\hline Neonate cuff (size 1) & Technol \\
\hline $\begin{array}{l}\text { Uniquet single-use latex-free } \\
\text { tourniquet }\end{array}$ & $\begin{array}{l}\text { Vacutainer brand, } \\
\text { Becton Dickinson }\end{array}$ \\
\hline $\begin{array}{l}\text { Insyte intravenous catheter and } \\
\text { needle unit, } 18 \text { - \& } 20 \text {-gauge, } 11 / 4 \text { in; } \\
22 \text {-gauge, } 1 \text { in }\end{array}$ & $\begin{array}{l}\text { Becton Dickinson, } \\
\text { Vascular Access }\end{array}$ \\
\hline Interlink injection site & Baxter \\
\hline Intravenous loops & $\begin{array}{l}\text { Polymicro } \\
\text { Technologies }\end{array}$ \\
\hline Microbore extension tubing & Baxter Healthcare \\
\hline \multicolumn{2}{|l|}{ Glass syringes } \\
\hline $\begin{array}{l}\text { LifeCare } 5000 \text { Plumset LifeShield } \\
\text { primary intravenous pump set - } \\
\text { OL } 15 \mathrm{gtt} / \mathrm{mL} \text { tubing }\end{array}$ & Abbott Laboratories \\
\hline Transpore 1-in tape & 3M/Baxter \\
\hline Steri-Strips $1 / 8$ in $\times 3$ in & 3M/Baxter \\
\hline $\begin{array}{l}\text { Bioclusive transparent dressing, } \\
4 \text { in } \times 5 \text { in, } 5 \text { in } \times 7 \text { in }\end{array}$ & $\begin{array}{l}\text { Johnson \& Johnson } \\
\text { Medical }\end{array}$ \\
\hline $\begin{array}{l}\text { Bardex all-silicone Foley catheter, } \\
16 \mathrm{~F} \text { and } 18 \mathrm{~F}\end{array}$ & $\begin{array}{l}\text { Bard Urological } \\
\text { Division }\end{array}$ \\
\hline
\end{tabular}

During regular physical examinations and preoperative history taking and physical examinations, patients who report a history of vague allergic reactions should be queried further for evidence of latex allergy (Table 3). Latex-sensitive patients undergoing surgery should be scheduled as the first case of the day, when aerosolized latex particles are the lowest. Larger hospitals should have a designated latex-free operating suite. If blood pressure cuffs and tubing are made of latex, the patient's extremities should be wrapped to prevent contact.

Although it has been recommended that medications not be drawn up through rubber-stoppered vials or allowed to sit in preloaded syringes that contain latex rubber, and that latex ports 
Table 7. Websites for Latex Allergy Information.

\begin{tabular}{ll}
\hline Organization & Address \\
\hline $\begin{array}{l}\text { PALS (Physicians Against } \\
\text { Latex Sensitization) }\end{array}$ & $\begin{array}{l}\text { e-mail: bzpmd@aol.com } \\
\text { http://www.pals.net/ } \\
\text { http//www.netcom.com/ } \\
\text { Latex Allergy Links page }\end{array}$ \\
$\begin{array}{l}\text { Delaware Valley Latex Allergy } \\
\text { http://www.latex.org/ }\end{array}$ \\
$\begin{array}{l}\text { ELASTIC (Education for } \\
\text { \& Information Coalition) }\end{array}$ & $\begin{array}{l}\text { e-mail: } \\
\text { ecbdmd@ix.netcom.com } \\
\text { http://www.netcom.com/ } \\
\text { NIOSH (National Institute }\end{array}$ \\
$\begin{array}{l}\text { hecbdmd/elastic.html } \\
\text { for Occupational Safety }\end{array}$ & latexall.hwtml \\
and Health) & \\
\hline
\end{tabular}

should not be used for intravenous injections, these precautions appear to be impractical for all but the most exquisitely latex-sensitive patient and are likely not necessary. ${ }^{38}$ Patients have been premedicated with antihistamines, steroids, and histamine $\mathrm{H}_{2}$-blockers, but anaphylactic reactions have occurred despite such pretreatment. ${ }^{38}$ Because the FDA has established rules for labeling all medical devices that contain natural rubber latex, ${ }^{39}$ the process of recognizing these products in the medical setting should be simplified.

Persons with latex hypersensitivity should possess epinephrine autoinjection kits and wear a medic alert identification. They should also carry diphenhydramine with them. Carrying extra pairs of nonlatex gloves for emergency medical or dental care is also advisable. Wearing a medic alert identification is important for the following reason: if an accident were to occur that would render the patient unconscious, the patient might be exposed to numerous medical products containing latex in the emergency department, including blood pressure cuff, urinary catheter, face mask, tourniquets, gloves, intravenous tubing, and so on, that could worsen the patient's symptoms and result in anaphylaxis.

Many household items, everyday products, and sports equipment are made of latex. Latex-allergic patients should allergy proof their homes and environment and be ready to recognize potential latex-containing products. In addition, patients should be educated about the cross-sensitivity between latex and certain fruits. They should also be aware that these cross-reactive fruits can be hidden in meals, such as in juice, liqueur, wine, fruit salad, ice cream, jam, chewing gum, potato chips, and cereal. ${ }^{32}$ With the increasing use of computers and Internet access, patients can be referred to several Websites to be informed about latex allergy (Table 7).

\section{Conclusion}

When caring for patients with latex allergy, the physician should educate patients about the potential hazards of latex-containing products. Health care providers should also develop a plan for protecting patients and health care workers from latex exposure and be able to manage allergic reactions when they occur.

\section{References}

1. Melton AL. Managing latex allergy in patients and health care workers. Cleve Clin J Med 1997;64(2): 76-82.

2. Kwittken P. Childhood latex allergy. Am J Asthma Allergy Ped 1992;6:27-33.

3. Sussman GL, Beezhold DH. Allergy to latex rubber. Ann Intern Med 1995;122:43-6.

4. Ownby DR, Ownby HE, McCullough J, Shafer AW. The prevalence of anti-latex $\operatorname{IgE}$ antibodies in 1000 volunteer blood donors. J Allergy Clin Immunol 1996;97:1188-92.

5. Porri F, Lemiere C, Birnbaum J, Guilloux L, Lanteaume A, Didelot R, et al. Prevalence of latex sensitization in subjects attending health screening: implications for a perioperative screening. Clin Exp Allergy 1997;27:413-7.

6. Gelfand DW. Barium enemas, latex balloons, and anaphylactic reactions. AJR Am J Roentgenol 1991; 156:1-2.

7. Kelly KJ, Kurup VP, Reijula KE, FinkJN. The diagnosis of natural rubber latex allergy. J Allergy Clin Immunol 1994;93:813-6.

8. Turjanmaa K, Reunala T, Tuimala R, Karkkainen T. Allergy to latex gloves: unusual complication during delivery. BMJ 1988;297:1029.

9. Lebenbom-Mansour MH, Oesterle JR, Ownby DR, Jennett MK, Post SK, Zaglaniczy K The incidence of latex sensitivity in ambulatory surgical patients: a correlation of historical factors with positive serum immunoglobulin E levels. Anesth Analg 1997;85:44-9.

10. Slater JE. Latex allergy. J Allergy Clin Immunol 1994;94(2 Pt 1):139-49.

11. Weido AJ, Sim TC. The burgeoning problem of latex sensitivity. Postgrad Med 1995;98:173-84.

12. Grzybowski M, Ownby DR, Peyser PA, Johnson $\mathrm{CC}$, Schork MA. The prevalence of anti-latex $\operatorname{IgE}$ antibodies among registered nurses. J Allergy Clin Immunol 1996;98:535-44.

13. Kibby T, Akl M. Prevalence of latex sensitization in a hospital employee population. Ann Allergy Asthma Immunol 1997;78:41-4. 
14. Liss GM, Sussman GL, Deal K, Brown S, Cividino M, Siu S, et al. Latex allergy: epidemiological study of 1351 hospital workers. Occup Environ Med 1997; 54:335-42.

15. Tarlo SM, Wong L, Roos J, Booth N. Occupational asthma caused by latex in a surgical glove manufacturing plant. J Allergy Clin Immunol 1990;85:62631.

16. Orfan NA, Reed R, Dykewicz MS, Ganz M, Kolski GB. Occupational asthma in a latex doll manufacturing plant. J Allergy Clin Immunol 1994;94:826-30.

17. Sussman GL, Tarlo S, Dolovich J. The spectrum of IgE-mediated responses to latex. JAMA $1991 ; 265: 2844-7$.

18. Vandenplas O, Delwiche JP, Evrard G, Aimont P, van der Brempt X, Jamart J, et al. Prevalence of occupational asthma due to latex among hospital personnel. Am J Respir Crit Care Med 1995;151:54-60.

19. Danne T, Niggemann B, Weber B, Wahn U. Prevalence of latex-specific IgE antibodies in atopic and nonatopic children with type I diabetes. Diabetes Care 1997;20:476-8.

20. Reinheimer G, Ownby DR. Prevalence of latex-specific IgE antibodies in patients being evaluated for allergy. Ann Allergy Asthma Immunol 1995;74:184-7.

21. Hamann CP. Latex hypersensitivity: an update. Allergy Proc 1994;15:17-20.

22. Pendle TD. The production, composition, and chemistry of natural latex concentrate [abstract]. Baltimore: International Latex Conference, November 1992. Abstract 1.

23. Tillotson TN. The manufacture of products from latex- an overview [abstract]. Baltimore: International Latex Conference, November 1992. Abstract 2.

24. Hammann CP. Natural rubber latex protein sensitivity in review. Am J Contact Derm 1993;4:4-21.

25. Reddy S. Latex allergy. Am Fam Physician 1998;57: 93-102, comment 42, 47.

26. Wrangsjo K, Montelius J, Eriksson M. Teats and pacifiers - an allergy risk for infants? Contact Dermatitis 1992;27:192-3.

27. Beezhold D, Beck WC. Surgical glove powders bind latex antigens. Arch Surg 1992;127:1354-7.
28. Kam PC, Lee MS, Thompson JF. Latex allergy: an emerging clinical and occupational health problem. Anaesthesia 1997;52:570-5.

29. Marcos C, Lazaro M, Fraj J, Quirce S, de la Hoz B, Fernandez-Rivas $M$, et al. Occupational asthma due to latex surgical gloves. Ann Allergy 1991;67:319-23.

30. Leynadier F, Pecquet C, Dry J. Anaphylaxis to latex during surgery. Anesthesia 1989;44:547-50.

31. Kearns CF, Norris A. Latex allergy and plastic syringes. Anesth Analg 1996;82:429.

32. Brehler R, Theissen U, Mohr C, Luger T. "Latexfruit syndrome": frequency of cross-reacting $\operatorname{IgE}$ antibodies. Allergy 1997;52:404-10.

33. Ownby DR, Tomlanovich M, Sammons N, McCullough J. Anaphylaxis associated with latex allergy during barium enema examinations. AJR Am J Roentgenol 1991;156:903-8.

34. Product approvals: latex sensitivity test. FDA Med Bull 1995;25:2-3.

35. Anaphylactic reactions during general anesthesia among pediatric patients - United States, January 1990 - January 1991. MMWR Morb Mortal Wkly Rep 1991;40:437, 443.

36. Woods JA, Lambert S, Platts-Mills TA, Drake DB, Edlich RF. Natural rubber latex allergy: spectrum, diagnostic approach, and therapy. J Emerg Med 1997;15:71-85.

37. Preventing allergic reactions to natural rubber latex in the workplace. US Department of Health and Human Services, Public Health Service, Centers for Disease Control Prevention, National Institute for Occupational Safety and Health. Cincinnati: Government Printing Office, 1997. DHHS (NIOSH) publication no. 97-135.

38. Kwittken PL, Becker J, Oyefara B, Danziger R, Pawlowski NA, Sweinberg S. Latex hypersensitivity reactions despite prophylaxis. Allergy Proc 1992;13: 123-7.

39. Food and Drug Administration. Latex-containing devices; user labeling; proposed rule. Fed Register 1996;61:32617-21. Retrieved 1997 from Federal Register Online via GPO access [wais.acess.gpo.gov], document no fr 24;96-46. 